Artigo original

Hegemonia - Revista Eletrônica do Programa de Mestrado em Direitos Humanos, Cidadania e Violência/Ciência Política do Centro Universitário Unieuro

ISSN: 1809-1261

UNIEURO, Brasília, número 26, Janeiro a Junho de 2019, pp. 40-65.

Recebido em: 2/06/2018

Avaliado em: 13/09/2018

Aprovado em: 16/10/2018

\title{
UMA ANÁLISE POLÍTICA DO DIREITO DE PUNIR DO ESTADO
}

Alexandre Pereira da Rocha ${ }^{1}$

RESUMO: Este artigo aborda o direito de punir do Estado numa perspectiva de poder político. Ou seja, é uma análise de teoria política sobre o direito de punir estatal. Com isso, pretende-se contribuir para o debate penitenciário observando que, a condição das prisões e como o tema é tratado pela sociedade contemporânea, não é apenas um dilema do campo criminal, mas, é essencialmente uma questão política.

PALAVRAS-CHAVE: criminologia, direito de punir estatal, poder político, sistema penitenciário.

ABSTRACT: This article addresses the State's punishment in the perspective of political power. That is, it is an analysis of political theory about the right to punish state. The aim is to contribute to the prison debate by observing that the condition of prisons and how the issue is treated by contemporary society is not only a dilemma of the criminal field, but is essentially a political issue.

KEYWORDS: criminology; State's punishment; political power; prison system.

"Toda grandez̧a, todo poder, toda subordinação

dependem do carrasco: ele é o horror e, por conseguinte, o elo da sociedade humana. Retirem do

mundo esse incompreensivel agente, nesse mesmo momento, a ordem será substituída pelo caos, tronos

cairão e a sociedade desaparecerá"

De Maistre

${ }^{1}$ Doutor em Ciências Sociais. 
Artigo original

Hegemonia - Revista Eletrônica do Programa de Mestrado em Direitos Humanos, Cidadania e Violência/Ciência Política do Centro Universitário Unieuro

ISSN: 1809-1261

UNIEURO, Brasília, número 26, Janeiro a Junho de 2019, pp. 40-65.

\section{Introdução}

Este artigo aborda o direito de punir do Estado numa perspectiva de poder político. Ou seja, é uma análise de teoria política sobre o direito de punir estatal. Com isso, pretende-se contribuir para o debate penitenciário observando que, a condição das prisões e como o tema é tratado pela sociedade contemporânea, não é apenas um dilema do campo criminal, mas, é essencialmente uma questão política.

Desse modo, resgata-se uma fundamentação teórica para compreender o papel punitivo do Estado. Todavia, adverte-se que, não se trata de uma genealogia do poder de punir, passando pela evolução histórica desse tipo de poder. Basicamente, esse trabalho tem como ponto de partida o período de formação dos Estados modernos, com o processo de centralização do poder político, e, em seguida, como o direito de punir estatal foi sendo transmutado, conforme vicissitudes do próprio Estado.

Para tanto, esse trabalho, fundamenta-se, especialmente, em Hobbes (2003) e Locke (2004), que abordam as bases do Estado e, assim, o direito de punir; além de e Beccaria (2002), Foucault (1987, 2003), Oliveira (2002a, 2002b), Zaffaroni et all (2003) e Zaffaroni (2013), que teorizaram e criticaram o poder punitivo estatal.

Sendo assim, numa primeira seção, analisa-se o direito de punir como elemento político em Hobbes e Locke. Na segunda seção, trata-se dos fundamentos do direito de punir em Beccaria, um dos percussores a firmar a pena ferramenta estatal. Na terceira seção, discorrese sobre o processo de mudança da punição como suplício para a concepção de ressocialização do criminoso. Na quarta seção, discute como nos dias de hoje o sistema penitenciário, ou seja, as prisões, constitui-se a materialização do direito de punir estatal.

2. Estado e direito de punir, em Hobbes e Locke

A discussão sobre o direito de punir do Estado não se resume ao estudo da evolução do direito penal, mas, processa-se numa análise da própria gênese do Estado. Tem-se que o direito de punir surge apenas com o Estado, pois anteriormente todos tinham o direito de se 
Artigo original

Hegemonia - Revista Eletrônica do Programa de Mestrado em Direitos Humanos, Cidadania e Violência/Ciência Política do Centro Universitário Unieuro

ISSN: 1809-1261

UNIEURO, Brasília, número 26, Janeiro a Junho de 2019, pp. 40-65.

defender e atacar, haja vista a inexistência de uma estrutura que monopolizasse o poder e tivesse capacidade de julgar.

O direito de punir implica o estabelecimento de uma pena, ou seja, uma sanção que recairá sobre aqueles indivíduos que confrontem a ordem dominante. Já no século XII, Foucault (2003, p. 56), apontava que o direito estatal era uma maneira regulamentada de ser fazer guerra. Com efeito, desde seu início o Estado se reveste do monopólio da violência, da capacidade de julgar e de impor punições. Desse modo, o direito de punir não está diluído na sociedade, mas centralizado e institucionalizado no Estado, e a penalidade é sua exclusividade. É a dinâmica dessa capacidade de impor penas aos indivíduos que é estudada neste artigo.

Em princípio, o direito de punir está intrinsecamente relacionado à formação do Estado. Portanto, é conveniente mostrar algumas concepções que o definem. Não é objetivo esmiuçar toda estrutura do Estado, mas apenas avocar algumas teorias que evidenciem suas origens. Dessa forma, busca-se a exposição de algumas ideias clássicas sobre a formação do Estado.

Nessa linha, destaca-se a definição de Thomas Hobbes (1651) sobre a gênese e desenvolvimento do Estado moderno. Em Hobbes, a história humana é definida em dois episódios: antes e depois do pacto. Anterior ao pacto, tinha-se o estado de natureza, regido pelo direito natural, o qual é:

A liberdade que cada um possui de usar seu próprio poder, à maneira que quiser, para preservação de sua própria natureza, ou seja, de sua vida. Consequentemente de fazer tudo aquilo que seu próprio julgamento e razão lhe indiquem como meios adequados a esse fim (HOBBES, 2003, p 101).

No entanto, o apelo ao direito natural conduz o homem à guerra generalizada. O fazer tudo de acordo seu próprio julgamento implica em concentrar todas suas forças para preservar a vida. Porque, embora as leis naturais sejam orientadas por virtudes, como a justiça, a equidade, a modéstia, a piedade, ou, em resumo, fazer aos outros o que queremos 
Artigo original

Hegemonia - Revista Eletrônica do Programa de Mestrado em Direitos Humanos, Cidadania e Violência/Ciência Política do Centro Universitário Unieuro

ISSN: 1809-1261

UNIEURO, Brasília, número 26, Janeiro a Junho de 2019, pp. 40-65.

que nos façam - por si mesmas, na ausência do temor de algum poder capaz de levá-las a ser respeitadas, são contrárias à paixão humana, as quais tendem para a parcialidade, o orgulho, a vingança e coisas semelhantes (HOBBES, 2003, p. 127).

Assim, segundo Hobbes, justifica-se a constituição do pacto, no qual os homens dispensariam o direito natural de fazer tudo que está ao seu alcance para preservar a vida pela harmonia em sociedade, onde uma estrutura soberana teria a tutela de todos. Pela regência do direito natural - do estado de natureza -, o homem vive na incerteza, sua vida é extensão de sua força física e mental. Já na sociedade, posterior ao pacto, embora a liberdade do homem seja limitada, encontra na figura do soberano a garantia para preservação da vida. Destarte, eis o motivo hobbesiano para o surgimento do Estado moderno:

Estado instituído é quando uma multidão de homens concordam e pactuam, cada um com um dos outros, que a qualquer homem ou assembleia de homens a quem seja atribuído pela maioria o direito de representar a pessoa de todos eles (ou seja, de ser seu representante), todos sem exceção, tanto os que votaram a favor dele como os que votaram contra ele, deverão autorizar todos os atos e decisões desse homem ou assembleia de homens, tal como se fossem seus próprios atos e decisões, a fim de viverem em paz uns com os outros e serem protegidos dos restantes homens (HOBBES, 2003, p. 132).

O Estado tem, assim, por objetivo estabelecer padrões de convivência entre os homens, visto que a guerra generalizada impossibilita o desenvolvimento da própria humanidade. A visão hobbesiana da gênese do Estado apresenta claramente a necessidade de o homem formar um corpo disciplinador, uma estrutura para impor penalidades aos contraventores da ordem, afinal, um Estado penal.

No Estado hobbesiano, o soberano tem o controle incondicional da vontade dos homens, uma vez que o soberano não faz parte da constituição do pacto. Ou seja, em Hobbes, quem se torna soberano, não faz antecipadamente nenhum pacto com seus súditos, 
Artigo original

Hegemonia - Revista Eletrônica do Programa de Mestrado em Direitos Humanos, Cidadania e Violência/Ciência Política do Centro Universitário Unieuro

ISSN: 1809-1261

UNIEURO, Brasília, número 26, Janeiro a Junho de 2019, pp. 40-65.

porque teria ou de celebrá-lo com toda a multidão, na qualidade de parte do pacto, ou que celebrar diversos pactos, um com cada um deles (HOBBES, 2003, p. 133).

O pacto é formado entre os homens, que relegam sua liberdade pela proteção do soberano. Por causa disso, o soberano - o Leviatã - é o juiz com capacidade de impor penalidades, não incumbindo mais aos homens clamar pelos seus direitos naturais para solucionar conflitos.

No desenho do Estado hobbesiano, portanto, verifica-se que o direito de punir é exclusividade do Estado, ou ainda, o direito de punir surge com o Estado. Anterior ao Estado inexistia o direito de punir, mas, sim, o direito natural de atacar e defender de cada indivíduo. Logo, só com a constituição do Estado as punições deixam de ser uma guerra, para se tornarem um direito. Dessa forma, o conflito não deixou de existir, mas passou a ser regulamentado pelo Estado.

Além da definição hobbesiana do Estado, acrescenta-se noutra vertente, o conceito de John Locke (1690). Não obstante, frisa-se a dessemelhança entre a noção de Estado em Hobbes e Locke, embora comunguem a necessidade de um corpo disciplinador. Assim, Hobbes e Locke concordam quanto à necessidade do Estado, mas têm entendimentos diferentes quanto ao controle do poder, pois, para o primeiro, o bom desempenho do poder estaria com o soberano; já para o segundo com o parlamento. Entretanto, essa diferença não invalida o argumento da estreita relação entre formação do estado e direito de punir. Portanto, examina-se a justificativa lockeana para edificação do Estado:

Sempre que, pois, certo número de indivíduos se reúne em sociedade, de tal modo que cada um abra mão do próprio poder de executar a lei de natureza, transferindo-o à comunidade, nesse caso, e somente nele, haverá uma sociedade civil ou política. E tal ocorre sempre que certo número de homens, no estado de natureza, se associa para constituir um povo, um corpo político sob um governo supremo, ou então quando qualquer indivíduo se junta ou se incorpora a uma comunidade já constituída; com isso autoriza a sociedade ou, o que vem a dar o mesmo, o poder legislativo dela a elaborar leis para ele, dentro da exigência do bem da sociedade, sendo que poderá ser solicitado seu auxílio para sua execução, como se fossem decretos dele mesmo. Dessa forma os homens saem do estado de natureza para entrarem no de comunidade, estabelecendo um juiz no mundo com autoridade para 
Artigo original

Hegemonia - Revista Eletrônica do Programa de Mestrado em Direitos Humanos, Cidadania e Violência/Ciência Política do Centro Universitário Unieuro

ISSN: 1809-1261

UNIEURO, Brasília, número 26, Janeiro a Junho de 2019, pp. 40-65.

deslindar todas as demandas e reparar os danos que atinjam qualquer membro da comunidade, juiz esse que é o legislativo, ou magistrado por ele nomeados (LOCKE, 2004, p. 70$)$.

O Estado lockeano surge em decorrência da preservação da propriedade (vida, liberdade e posses), porque o estado de naturez̧a não oferecia garantia plena da preservação da mesma. Diferentemente de Hobbes, para Locke o estado de natureza não é caracterizado pela guerra generalizada. Trata-se de um estágio onde os homens convivem com relativa harmonia, sem uma autoridade superior comum no mundo que possa julgar entre eles. Todavia, o uso da força, ou sua intenção declarada, contra a pessoa de outrem, quando não existe nenhuma instância superior comum sobre a Terra para quem apelar, (conduz) configura o estado de guerra (LOCKE, 2004, p. 32). É pelas desvantagens do estado de guerra que se justifica a necessidade do Estado:

E assim a comunidade consegue, por meio de um poder julgador, fixar o castigo cabível às várias transgressões quando perpetradas entre os membros dessa sociedade - o que é o poder de fazer as leis -, e também possui poder de punir qualquer ofensa praticada contra qualquer dos membros por alguém que não pertence a ela - que é o poder de guerra e de paz; e tudo isso visando a preservação da propriedade de cada membro dessa sociedade, tanto quanto possível (LOCKE, 2004, p. 70).

Assim, encontramos tanto em Hobbes, como em Locke, a necessidade de se criar uma estrutura capaz de julgar todos os indivíduos: o Estado. Ou seja, um elemento que contenha o poder de todos e que suas atitudes sejam acatadas por todos. Portanto, de forma simplificada, o Estado, seria o poder de todos os homens reunidos em uma única instituição. A partir dessa definição do Estado - que é apenas uma visão entre muitas que o definem tem-se que ora criticando, ora aprimorando, ora destruindo, o Estado, constitui-se num conceito que se enquadra em diversos matizes políticos, mas, o direito de punir dele tem se preservado. Por conta disso, a compreensão do Estado moderno serve para o propósito 
Artigo original

Hegemonia - Revista Eletrônica do Programa de Mestrado em Direitos Humanos, Cidadania e Violência/Ciência Política do Centro Universitário Unieuro

ISSN: $1809-1261$

UNIEURO, Brasília, número 26, Janeiro a Junho de 2019, pp. 40-65.

primordial deste ensaio, que é defender que sua gênese possui estreita relação com o direito de punir contemporâneo.

\section{Os Fundamentos políticos do Direito de Punir do Estado}

A despeito das diferenças conceituais e ideológicas, Hobbes e Locke apontam para formação de uma instituição que concentre o direito de punir. No entanto, os homens não pactuaram simplesmente para perder as liberdades naturais, mas para que o exercício dessas liberdades não os conduza ao conflito. Com efeito, o direito de punir surge a partir da afronta ao pacto, da possibilidade de conflito, ou seja, do insulto ao poder soberano, como defende Hobbes; ou ao abalo da lei estabelecida pela sociedade civil, de acordo com Locke. Mesmo assim, questiona-se: em que se funda o direito de punir?

Essa questão é a base do estudo de Cesare Beccaria, que, na obra Dos Delitos e das Penas editada em 1763, analisa o direito penal, ou melhor o direito de punir de sua época. Beccaria critica a crueza das penas praticadas pelo Estado em nome de todos. Assim, define os fundamentos do direito de punir:

Fadigados de só viver em meio a temores e de encontrar inimigos em toda parte, cansados de uma liberdade cuja incerteza de conservá-la tornava inútil, sacrificaram uma parte dela para usufruir do restante da segurança. A soma dessas partes de liberdade assim sacrificadas ao bem geral, constitui a soberania na nação; e aqueles que foi encarregado pelas leis como depositário dessas liberdades e dos trabalhos da administração foi proclamado soberano do povo (...) Desse modo, somente a necessidade obriga os homens a ceder uma parcela de sua liberdade; disso advém que cada qual apenas concorda em pôr no depósito comum a menor porção possível dela, quer dizer, exatamente o que era necessário para empenhar os outros em mantê-lo na posse do restante. A reunião de todas essas 
Artigo original

Hegemonia - Revista Eletrônica do Programa de Mestrado em Direitos Humanos, Cidadania e Violência/Ciência Política do Centro Universitário Unieuro

ISSN: $1809-1261$

UNIEURO, Brasília, número 26, Janeiro a Junho de 2019, pp. 40-65.

pequenas parcelas de liberdade constitui o fundamento do direito de punir (BECCARIA, 2004, p. 19).

O direito de punir, portanto, funda-se na prerrogativa de abolir a incerteza particular do estado norteado exclusivamente pelas leis naturais, onde o desejo de preservação da vida ou propriedade pode levar ao conflito.

O direito de punir se forma com a soma das liberdades naturais de cada indivíduo, que as transfere para uma instituição comum a todos. Dessa forma, a justificativa de Beccaria para as origens do direito de punir é semelhante à que Hobbes e Locke aplicam à formação do Estado. Em Hobbes, os homens relegam suas liberdades naturais por causa do desgaste da guerra generalizada, própria do estado de natureza. Logo instituem um soberano que lhes proporcione segurança e preservação da vida. Em Locke, os homens deixam as liberdades naturais não necessariamente pelo temor, mas pelas vantagens da sociedade civil, que estabelece leis às quais todos se submetem no intuito de preservar a propriedade.

Desse modo, na proporção que os homens relegam a completude de suas liberdades naturais - a possibilidade ilimitada de fazer tudo ao seu alcance -, seja para um soberano, ou para um corpo coletivo, enfim para uma instituição denominada Estado, também concede a esta mesma instituição o direito de punir aqueles que confrontem a ordem pactuada ou estabelecida.

O direito de punir aplica-se a todos indistintamente, não se podendo proclamar o não-consentimento ao pacto, a não-submissão ao Leviatã hobbesiano, ou as leis da sociedade civil lockeana. O Estado serve para preservar a vida ou propriedade, mas também para impor sanções àqueles que confrontem o entendimento comum. Desse modo, o direito de punir manifestou-se com o primeiro homem que se rebelou, que avocou a plenitude de suas liberdades naturais em detrimento à liberdade dos outros ou frente ao próprio Estado.

Para Beccaria (2004) as penas decorrem unicamente do Estado, sendo que as penas que vão além da necessidade de manter o "depósito da salvação pública” são injustas por sua natureza; e tanto mais justas serão quanto mais sagrada e inviolável for a segurança e maior a liberdade que o soberano proporcionar aos súditos. 
Artigo original

Hegemonia - Revista Eletrônica do Programa de Mestrado em Direitos Humanos, Cidadania e Violência/Ciência Política do Centro Universitário Unieuro

ISSN: 1809-1261

UNIEURO, Brasília, número 26, Janeiro a Junho de 2019, pp. 40-65.

Tal condição afasta Beccaria de Hobbes e o aproxima de Locke, quanto à amplitude da penalidade e posicionamento ideológico do Estado. Beccaria confronta justamente o Estado absolutista defendido por Hobbes, para quem o soberano praticamente não tem limites. No império do absolutismo, verificou-se o exercício das punições sedimentadas em medidas cruéis e sangrentas. Embora todos os indivíduos estejam sujeitos ao direito de punir do Estado, não cabe a este lhes retirar a humanidade, pois todo exercício do poder que deste fundamento se afasta constitui abuso e não justiça (BECCARIA, 2004, p. 20). Essa é a principal crítica que Beccaria tece ao Estado absolutista.

Beccaria reconhece a necessidade de uma instituição reguladora do direito de punir, que surge com o estabelecimento do contrato. No entanto, o direito de punir não pode ser propriedade do soberano, que o exerce da forma que lhe aprouver. Portanto, deve ser fruto de leis provenientes da sociedade civil. Já se discorreu que Hobbes e Locke, apesar das distinções, aludem à necessidade de uma instituição que detenha o direito de punir, também Beccaria assume o mesmo entendimento. Entretanto, as críticas de Beccaria ao poder irrestrito do soberano e à proclamação dos direitos civis acompanham justamente o processo de transformação do Estado absolutista para o Estado de direito.

O direito de punir está sujeito às vicissitudes do formato do Estado, bem como de quem o controla. Por isso, a importância do estabelecimento de leis que não reflitam o desejo isolado do soberano, mas a vontade coletiva. A lógica do respeito às leis provém da própria necessidade de preservar a vida. Foram as leis que agruparam os homens, no início independentes e isolados, à superfície da terra (BECCARIA, 2004, p. 18). No entanto, as leis também estão sujeitas aos percalços da injustiça, pois, as mesmas leis que possibilitaram aos homens o convívio em sociedade, trouxeram-lhe muitos tormentos.

Note-se que, o direito de punir concedido ao Estado foi usurpado por muitos reis e governantes que se aproveitavam das leis para punir por situações que ultrapassavam o limite do delito. Com isso a humanidade foi vítima do jugo da inexorável superstição, avareza e ambição de um reduzido número de homens poderosos, que não se furtam de encher de sangue humano os palácios dos senhores e os tronos dos reis (BECCARIA, 2004, p. 25). Não obstante, a partir do delineamento do Estado moderno de Hobbes e Locke, e das considerações de Beccaria, constituiu-se os fundamentos do direito de punir do Estado, sendo que esse poder punitivo é um fato político (ZAFFANORI et alli, 2003) 
Artigo original

Hegemonia - Revista Eletrônica do Programa de Mestrado em Direitos Humanos, Cidadania e Violência/Ciência Política do Centro Universitário Unieuro

ISSN: 1809-1261

UNIEURO, Brasília, número 26, Janeiro a Junho de 2019, pp. 40-65.

Na esteira dos pensadores modernos, já no século XIX, Max Weber (2000) aponta como principal característica do Estado o monopólio da violência. Apenas o Estado tem o direito de estabelecer punições. Assim, tanto a definição do Estado moderno como a do Estado contemporâneo, contemplam o direito de punir. Enfim, o direito de punir está adstrito ao Estado, que a despeito de como é conduzido, seja por soberano ou parlamento, situa-se numa posição onipotente perante a sociedade, no qual lhe incumbe fazer e impor leis, às quais terão que ser obedecidas por todos os indivíduos. Eis a base do direito de punir do Estado.

4. Do Suplício do Estado Absoluto à Ressocialização do Estado de direito

A história do direito de punir flutua num assombroso mar de sangue, no qual o tormento físico era uma maneira de reparar o delito cometido, visando não a alcançar uma justiça, mas, sim, uma vingança, que era imposta pelo Estado em nome do soberano ou da comunidade.

Tem-se que, as primeiras punições tinham a função de degradar fisicamente a figura do contraventor. Ressalte-se que elas não se limitavam ao plano civil, mas estavam arraigadas em interesses religiosos, no qual por meio do tormento físico buscava-se a elucidação e reparação do crime, bem como a salvação da alma (FOUCALT, 1987; 2003). Entretanto, gradativamente, essa forma de punição foi perdendo legitimidade pela sociedade, pois as cruezas das penas se tornaram apenas num teatro macabro que não reparava nem impedia o crime.

Nos primórdios do direito de punir do Estado as penas mais comuns eram o banimento e a multa. Todavia as que mais despertam atenção eram os tormentos físicos, ou seja, os suplícios. A prisão como pena que serve de meio à reeducação só foi inaugurada com a House of Corretion, em Londres, no ano de 1550 (OLIVEIRA, 2002, p. 58). O suplício, como forma de punição, ao nosso olhar contemporâneo, parece algo extremamente aleatório e depredador. Porém, para sociedade medieval e anteriores era uma técnica precisa de reparação do crime, tanto que: 
Artigo original

Hegemonia - Revista Eletrônica do Programa de Mestrado em Direitos Humanos, Cidadania e Violência/Ciência Política do Centro Universitário Unieuro

ISSN: 1809-1261

UNIEURO, Brasília, número 26, Janeiro a Junho de 2019, pp. 40-65.

Uma pena, para ser suplício, deve obedecer a três critérios principais: em primeiro lugar, produzir uma certa quantidade de sofrimento que se possa, senão medir exatamente, ao menos apreciar, comparar e hierarquizar; a morte é um suplício na medida em que ela não é simplesmente privação do direito de viver, mas a ocasião e o termo final de uma graduação calculada de sofrimentos: desde a decapitação - que reduz todos os sofrimentos a um só gesto e num só instante: o grau zero de suplício - até o esquartejamento que os leva quase ao infinito, através do enforcamento, da fogueira e da roda, na qual se agoniza muito tempo; a morte-suplício é arte de reter a vida no sofrimento, subdividindo-a em "mil mortes" e obtendo, antes de cessar a existência, the most exquisite agonies. O suplício repousa na arte quantitativa do sofrimento. Mas não é só: esta produção é regulada. O suplício faz correlacionar o tido de ferimento físico, a qualidade, a intensidade, o tempo dos sofrimentos com a gravidade do crime, a pessoa do criminoso, o nível social de suas vítimas (FOUCAULT, 1987, p. 31).

Note-se que, definimos o direito de punir como monopólio do Estado. No entanto, isso não implica que as punições sejam justas ou morais. Desse modo, as primeiras punições ocorriam à revelia do acusado, que não tinha direito de defesa, como constituir advogado, conhecer partes do processo, ou nem sequer conhecer quem o estava acusando. Os tribunais eram obscuros, pois todo o processo criminal, até a sentença, permanecia secreto, ou seja, opaco não só para o público, mas o próprio acusado (FOUCAULT, 1987, p. 32).

Nesse caso, a acusação prevalecia sobre o acusado, pois se configurava na vontade do soberano, isto é, no exercício do direito de punir do Estado. Por causa disso, a forma secreta e escrita do processo confere com o princípio de que em matéria criminal o estabelecimento da verdade era para o soberano e seus juízes um direito absoluto e um poder exclusivo (FOUCAULT, 1987, p. 33).

Não obstante, a sistemática do direito de punir teve grande modificação a partir do século XVIII, à medida que a forma de punição do Estado absoluto foi sendo substituída por um ideário no qual a aplicação das penas não deveria traduzir-se em vinganças coletivas, mas, antes, objetivar a justiça, a prevenção do crime, e a recuperação do criminoso (BECCARIA, 2004, p. 126). 
Artigo original

Hegemonia - Revista Eletrônica do Programa de Mestrado em Direitos Humanos, Cidadania e Violência/Ciência Política do Centro Universitário Unieuro

ISSN: 1809-1261

UNIEURO, Brasília, número 26, Janeiro a Junho de 2019, pp. 40-65.

Dessa forma, como o Estado passou por transformações, por conta das revoluções liberais dos séculos XVIII e XIX, as penas também. Surge, destarte, um movimento no sentido de criticar as atitudes obscuras que envolviam a punição, sendo que seus principais expoentes foram: Cesare Beccaria com a obra Dos Delitos e das Penas (1764) e John Howard com O Estado das Prisões na Inglaterra e País de Gales (1776).

Tais obras foram pioneiras no combate à tradição jurídica e à legislação penal da época, pois criticavam os julgamentos secretos, os suplícios, as torturas como forma de obter a prova e a reparação do crime. Deu-se o início ao período humanitário das prisões, não porque elas se tornassem verdadeiramente humanas, mas porque foram expostas ao público as verdades que todos sentiam e sussurravam em relação aos abusos, atrocidades e injustiças contra as pessoas sujeitas, através dos séculos, ao frio aprisionamento (OLIVEIRA, 2002, p. $58)$.

Ocorreu, portanto, um processo de moderação da pena, tanto que a punição paulatinamente deixa de ser uma indumentária do medo que o Estado usava para expressar sua força. Logo, tudo o que pudesse implicar espetáculo desde então teria um cunho negativo, e como as funções da cerimônia penal deixaram pouco a pouco de ser compreendidas, ficou a suspeita de que tal rito, que dava um "fecho" ao crime, mantinha com ele afinidades espúrias, igualando-o, ou mesmo ultrapassando-o em selvageria (FOUCAULT, 1987, p. 12).

O Estado, ao estabelecer penas violentas, estava se igualando ao criminoso, por sua vez, a reparação do crime mediante suplícios não encontrava mais legitimidade popular. Logo o objetivo da pena, que era também promover medo ao povo, gradativamente se tornava objeto de revolta. Desse modo, como frisa Foucault, o condenado se tornava herói pela enormidade de seus crimes largamente propalados, e às vezes pela afirmação de seu arrependimento tardio. Com efeito, contra a lei, contra os ricos, os poderosos, os magistrados, a polícia montada ou a patrulha, contra o fisco e seus agentes, o criminoso aparecia como alguém que tivesse travado um combate em que todos se reconheciam facilmente (FOUCAULT, 1987, p. 55).

Com efeito, de réu, em muitos casos, o condenado passava a mártir, pois bravamente lutava contra o poder do soberano. Logo o esfacelamento de seu corpo acabava por minar 
Artigo original

Hegemonia - Revista Eletrônica do Programa de Mestrado em Direitos Humanos, Cidadania e Violência/Ciência Política do Centro Universitário Unieuro

ISSN: 1809-1261

UNIEURO, Brasília, número 26, Janeiro a Junho de 2019, pp. 40-65.

as bases dos tronos. Se o condenado se mostrava arrependido, aceitando o veredicto, pedindo perdão a Deus e aos homens por seus crimes, era visto purificado; morria, à sua maneira, como um santo. Mas até sua irredutibilidade lhe dava grandeza: não cedendo aos suplícios, mostrava uma força que nenhum poder conseguia dobrar (FOUCAULT, 1987, p. 55). Os ladrões, homicidas, vagabundos, indigentes, até o início do século XIX, tinham suas mortes usadas como forma de contestação à estrutura vigente. O horror ao invés de reprimir, passou a gerar uma insatisfação generalizada. Resultado: o embate ao direito de punir constituía-se numa insatisfação ao poder do soberano, do Estado absolutista, tanto que a Revolução Francesa (1789) teve como ícone a derrubada da prisão de Bastilha, pois:

É curioso notar que, em meio aos movimentos de reforma do regime carcerário, adveio a Revolução Francesa. E o que então se viu foi o povo de Paris investir contra a Bastilha, para ele o símbolo da opressão. A Bastilha era uma antiga fortaleza construída em 1370, em Paris, pelo rei Charles V. No século XVII, no Governo do Cardeal Richelieu, a Bastilha foi transformada em prisão para encarcerar até mesmo os que desagradavam ao rei ou à sua corte. Quando a Revolução Francesa começou, a primeira coisa que o povo fez foi atacar e destruir a Bastilha, no dia 14 de julho de 1789. A Bastilha foi, antes de tudo, a imagem do despotismo na França. Por isso mesmo, a derrubada de tal bastião do absolutismo sempre representa na luta da humanidade contra a prepotência (OLIVEIRA, 2002, p. 58).

Em virtude disso, o direito de punir do Estado passa por reformas, seguindo o processo de humanização da pena, que substitui o espetáculo do horror das punições em praça pública, por critérios mais subjetivos, sendo assim:

A punição vai-se tornando, pois, a parte mais velada do processo penal, provocando várias consequências: deixa o campo da percepção quase diária e entra no da consciência abstrata; sua eficácia é atribuída à sua 
Artigo original

Hegemonia - Revista Eletrônica do Programa de Mestrado em Direitos Humanos, Cidadania e Violência/Ciência Política do Centro Universitário Unieuro

ISSN: $1809-1261$

UNIEURO, Brasília, número 26, Janeiro a Junho de 2019, pp. 40-65.

fatalidade não à sua intensidade visível; a certeza de ser punido é que deve desviar o homem do crime e não mais o abominável teatro; a mecânica exemplar da punição muda as engrenagens (FOUCAULT, 1987, p. 13).

Os interesses que uniram os homens em sociedade concedendo o monopólio da violência ao soberano, ou seja, ao Estado, não justificava mais as punições físicas, os suplícios e as torturas. O direito de punir, por sua vez, deveria representar também os anseios da sociedade. Caso contrário - como anunciou Beccaria -, constitui-se abuso e não justiça, isto é, um poder de fato e não de direito, constitui usurpação e jamais um poder legítimo (BECCARIA, 2004, p. 20).

A referida transformação do direito de punir foi acompanhada pelo desenvolvimento do Estado, que deixa de ser absoluto e se transforma em Estado de direito, no qual mecanismos constitucionais impedem ou obstaculizam o exercício arbitrário e ilegítimo do poder e impedem ou desencorajam o abuso ou o exercício ilegal do poder (BOBBIO, 1987, p. 19). Mais uma vez, mostrando a estreita relação entre as razões do Estado e o direito de punir, tem-se que o processo de transformação do Estado entre os séculos XVIII e XIX foi acompanhado por mudanças no aspecto punitivo. Beccaria apresenta princípios que justificam a mudança do direito de punir do Estado, a saber:

Apenas as leis podem indicar as penas de cada delito e que o direito de estabelecer leis penais não pode ser senão da pessoa do legislador, que representa toda a sociedade ligada por um contrato social. (..) A segunda consequência é a de que o soberano, representando a própria sociedade, apenas pode fazer leis gerais, às quais todos devem obediência; não é de usa competência, contudo, julgar se alguém violou tais leis. (...) Em terceiro lugar, ainda que a atrocidade das penas não fosse reprovada pela filosofia, que é a mãe das virtudes benéficas e, por esse motivo, esclarecida, que prefere governar homens felizes e livres a dominar covardemente um rebanho de tímidos escravos; ainda que os castigos cruéis não se opusessem diretamente ao bem público e à finalidade que se lhes atribui, 
Artigo original

Hegemonia - Revista Eletrônica do Programa de Mestrado em Direitos Humanos, Cidadania e Violência/Ciência Política do Centro Universitário Unieuro

ISSN: $1809-1261$

UNIEURO, Brasília, número 26, Janeiro a Junho de 2019, pp. 40-65.

a de obstar os crimes, será então odiosa, revoltante, em desacordo com a justiça e com a natureza do contrato social (BECCARIA, 2004, p. 21).

Surge, portanto, o contraste entre o Estado Absoluto e outra forma de Estado que ressalta os princípios da legitimidade baseada na lei. No Estado absoluto, o direito de punir assumia uma função bastante específica, pois o crime além de sua vítima imediata ataca o soberano; ataca-o pessoalmente, pois a lei vale como a vontade do soberano; ataca-o fisicamente, pois a força da lei é a força do príncipe (BECCARIA, 2004, p. 41). Já no Estado Direito, o crime não assume a mesma função, pois se configura numa afronta aos indivíduos e não necessariamente às leis impostas, haja vista o Estado ter restringido sua referência como soberano.

Desse modo, no Estado absoluto, a pena não restabelecia a justiça; mas reativa o poder, pois, em todo crime há uma espécie de sublevação contra a lei e que o criminoso é um inimigo do príncipe (BECCARIA, 2004, p. 43). Não obstante, no Estado Direito, almejase estabelecer a justiça. O poder não é exaltado como forma de vingança, porque o criminoso não é um inimigo do Estado. Pelo contrário, é um indivíduo que deve ser punido dentro de um devido processo legal, com direitos e garantias frente ao poder estatal.

Numa pesquisa sobre a história das prisões francesas, Foucault (1987), intitula esse processo de "afrouxamento da severidade penal". Tem-se, portanto, redução de intensidade, e também mudança do aspecto dos objetivos. Desse modo, o direito de punir do Estado deve continuar, sem, contudo, eliminar o criminoso. Sobretudo, deve buscar meios de transformá-lo por meio das punições num indivíduo que possa conviver novamente em sociedade.

Nesse sentido, destaca-se outro estudo pioneiro ainda do século XIX, de Jeremias Bentham, Teoria das Penas e das Recompensas (1819). Nessa obra, delineia-se o processo punitivo contemporâneo, apresentando uma nova concepção de penitenciária, um modelo arquitetônico inovador com celas distribuídas em forma de raios, merecendo ênfase o sentido correcional da prisão com separação dos presos por sexo, a importância de adequada alimentação, vestuário, limpeza, trabalho, assistência à saúde, educação e ajuda aos liberados (OLIVEIRA, 2002b, p. 60). 
Artigo original

Hegemonia - Revista Eletrônica do Programa de Mestrado em Direitos Humanos, Cidadania e Violência/Ciência Política do Centro Universitário Unieuro

ISSN: $1809-1261$

UNIEURO, Brasília, número 26, Janeiro a Junho de 2019, pp. 40-65.

Tem-se que a pena era tida apenas como retribuição ou prevenção criminal, mas hoje, a partir do fortalecimento do Estado Direito, a pena adquiriu uma finalidade maior que é reeducar o criminoso que demonstra sua inadaptabilidade social. Portanto, a execução penal (o direito de punir) deve promover a transformação do criminoso em não-criminoso, possibilitando-se métodos coativos para se operar a mudança de suas atitudes e de seu comportamento social (BARROS, 2002, p. 8). Essa é a tônica, ou utopia, do direito de punir hodierno.

5. As prisões como materialização do Direito de Punir

Foi dito que o direito de punir do Estado funda-se em sua característica de detentor legítimo do uso da força, a qual é usada para o controle social. Todavia, quando o uso da força não é mais suficiente, pois o crime já foi cometido, cabe ao Estado exercer o seu direito de punir, assim, estabelecendo uma pena ao contraventor da ordem. A pena é oriunda de um complexo de normas que sedimentam o direito de punir, como uma economia da punição. O que, decerto, transformou o fenômeno de humanização da pena, não se observa, por exemplo, a punição mediante violências físicas, mas, sim, numa restrição de direitos, principalmente da liberdade.

Até início do século XVII, a prisão era uma mera medida cautelar, um procedimento provisório, até que a pena principal fosse proferida. Somente no final do referido século que a pena privativa de liberdade se institucionalizava como principal sanção penal, e a prisão passa a ser, fundamentalmente, o local da execução das penas. Nascem, então, as primeiras reflexões sobre a organização das casas de detenção e sobre as condições de vida dos detentos, de caráter marcadamente administrativo ${ }^{2}$.

O Estado de direito é, portanto, responsável pelo criminoso. Como já se dissemos, deve transformá-lo num indivíduo capaz de viver em sociedade, de respeitar os

${ }^{2}$ CURSO DE FORMAÇ̃̃O de Agente Penitenciário da Policia Civil do DF. Noções de Direito Penitenciário, 2001. 
Artigo original

Hegemonia - Revista Eletrônica do Programa de Mestrado em Direitos Humanos, Cidadania e Violência/Ciência Política do Centro Universitário Unieuro

ISSN: 1809-1261

UNIEURO, Brasília, número 26, Janeiro a Junho de 2019, pp. 40-65.

ordenamentos jurídicos e a sociedade. Por causa disso, o direito de punir, que outrora em grande parte liquidava o criminoso, converte-se numa instituição que ao mesmo tempo em que pune, também cuida. Desse modo, tem-se a complexidade do sistema penitenciário contemporâneo, isto é, da materialização do direito de punir estatal. Daí são nos presídios, penitenciárias e cadeias que se observam o resultado da pena, que são indivíduos presos por terem afrontado o uso da força do Estado e descumprido o ordenamento jurídico-social.

O sistema penitenciário constitui-se, portanto, numa das formas de o Estado exercer seu direito de punir, de controle social. Desse modo, tem-se o surgimento do direito penitenciário, como um conjunto de normas que regulam toda a execução da reprimenda, seus objetivos, tratamento ao preso e organização penitenciária ${ }^{3}$.

O sistema penitenciário acompanhou as transformações do Estado, bem como foi fruto de várias experiências e estudos. Nesse cenário, destacam-se os Sistemas Penitenciários Clássicos, desenvolvidos no intuito de dotar o modelo de privação de liberdade com medidas que aliviassem o pesadelo da contínua violação dos direitos humanos no cárcere e possibilitando, igualmente, a real correção dos delinquentes (OLIVEIRA, 2002b, p. 61).

Em decorrência disso, diversos Estados buscaram o estabelecimento de legislações e códigos sobre a questão penitenciária, como ocorreu na Rússia, 1769; Prússia, 1780; Pensilvânia e Toscana, 1786; Áustria, 1788; França, 1791, Ano IV, 1808 e 1810. Para justiça penal, uma era nova (FOUCAULT, 1987, p. 11).

Com o estabelecimento do Estado de direito, o processo punitivo gradativamente assentou-se no estabelecimento de leis que passaram a prescrever a pena. $O$ sistema penitenciário, constitui-se na expressão concreta do direito de punir do Estado, outrossim é o aparelho que possibilita a aplicação da pena. No desenvolvimento do processo punitivo, a partir do surgimento das prisões, vários métodos foram aplicados no objetivo de reformar o delinquente. Abaixo se expõem os principais modelos prisionais, os quais foram fundamentais para a estruturação do sistema penitenciário contemporâneo:

\footnotetext{
${ }^{3}$ CURSO DE FORMAÇÃO de Agente Penitenciário da Policia Civil do DF, 2001.
} 
Artigo original

Hegemonia - Revista Eletrônica do Programa de Mestrado em Direitos Humanos, Cidadania e Violência/Ciência Política do Centro Universitário Unieuro

ISSN: 1809-1261

UNIEURO, Brasília, número 26, Janeiro a Junho de 2019, pp. 40-65.

Quadro 1: Modelos Clássicos de Sistemas Penitenciários

\begin{tabular}{|c|c|}
\hline Sistema & Descrição \\
\hline Pensilvânico & $\begin{array}{l}\text { Desenvolvido na Filadélfia em 1829, na Eastean Penitentiary, tendo por base } \\
\text { o modelo de Jeremias Bentham. A base do modelo pensilvânico era o } \\
\text { isolamento celular, com trabalho no próprio interior da cela, separando os } \\
\text { presos para evitar promiscuidade e fazer com que todos meditassem sobre } \\
\text { seus crimes com o objetivo de melhorar a pessoal. A solidão foi tão cruel, } \\
\text { no estado de espírito dos enclausurados, que muitos foram vítimas de } \\
\text { loucura. }\end{array}$ \\
\hline Auburiano & $\begin{array}{l}\text { Desenvolvido na Penitenciária de Auburn, em Nova York, a partir } 1818 \text {. } \\
\text { Impunha trabalho em comum durante o dia, sob absoluto silêncio, } \\
\text { punindo com variados castigos qualquer tentativa de comunicação. À } \\
\text { noite, o isolamento celular também era absoluto para descanso da labuta } \\
\text { diária e com meio de evitar a corrupção dos condenados. Ficou conhecido } \\
\text { no Estados Unidos como: silent system. }\end{array}$ \\
\hline $\begin{array}{l}\text { Progressivo } \\
\text { Inglês } \\
\text { (Mark System) }\end{array}$ & $\begin{array}{l}\text { Surgiu na Inglaterra em 1840, motivado pelas deficiências do Modelo } \\
\text { Pensilvânico e Auburiano. O Mark System estabeleceu uma forma de } \\
\text { indeterminação da pena, que era medida em razão do trabalho, da boa } \\
\text { conduta do condenado e levando em conta a gravidade do delito praticado. } \\
\text { Com base nesses três fatores, eram atribuídas marcas ou vales, diariamente, } \\
\text { que poderiam ser subtraídas em razão das faltas praticadas. Ao obter } \\
\text { determinado número de marcas ou vales, o condenado era posto em } \\
\text { liberdade. }\end{array}$ \\
\hline $\begin{array}{l}\text { Progressivo } \\
\text { Irlandês }\end{array}$ & $\begin{array}{l}\text { Criado em 1854, diferia do Sistema Progressivo Inglês. O Sistema Inglês } \\
\text { contém três períodos de execução da pena, enquanto no Irlandês há quatro, } \\
\text { pois introduziu um período intermediário entre a prisão em comum } \\
\text { (segundo período do Sistema Inglês) e o livramento condicional. Nesse } \\
\text { período intermediário, com o feitio de antecedente da prisão aberta, foi } \\
\text { adotado o trabalho externo que preparava o preso para o futuro com } \\
\text { obtenção do Ticket of leave (liberdade condicional). Além disso, os detidos } \\
\text { não eram obrigados aguardar silêncio durante o trabalho em comum. }\end{array}$ \\
\hline Elmira & $\begin{array}{l}\text { Baseado no Sistema Progressivo Irlandês surgiram no Estados Unidos os } \\
\text { Regimes Reformatórios, cujo mais famoso foi o Sistema do Reformatório } \\
\text { de Elmira, em Nova York em 1869. Nesse sistema, a reação contra a } \\
\text { criminalidade pela cura do condenado se apresenta mais claramente na } \\
\text { evolução prática da política penitenciária. Criou-se o sistema unitário de } \\
\text { pena e medida de segurança, mediante o critério de avaliação do } \\
\text { condenado, logo após o condenado passar por uma classificação inicial, era } \\
\text { submetido a um sistema de marcas e vales, concedidas em razão da evolução } \\
\text { do trabalho, boa conduta, instrução moral e religiosa. O aprendizado de }\end{array}$ \\
\hline
\end{tabular}


Artigo original

Hegemonia - Revista Eletrônica do Programa de Mestrado em Direitos Humanos, Cidadania e Violência/Ciência Política do Centro Universitário Unieuro

ISSN: $1809-1261$

UNIEURO, Brasília, número 26, Janeiro a Junho de 2019, pp. 40-65.

\begin{tabular}{|c|c|}
\hline & $\begin{array}{l}\text { um oficio era obrigatório e a disciplina era do tipo militar. Quando } \\
\text { alcançava a terceira fase, o apenado tinha direito ao livramento condicional } \\
\text { e recebia um pecúlio, como forma de ajuda financeira para as primeiras } \\
\text { necessidades. }\end{array}$ \\
\hline Montesinos & $\begin{array}{l}\text { Em 1835, no Presídio de Valência na Espanha, implantou-se um } \\
\text { diferenciado e eficiente regime prisional, baseado no exercício humanitário } \\
\text { da prisão. Principais características: a) não admitia o regime celular; b) } \\
\text { menos castigo e mais autoridade moral; c) equilíbrio entre o exercício da } \\
\text { autoridade e a missão pedagógica; d) nenhuma sansão disciplinar deveria } \\
\text { ter caráter infame; e) o poder disciplinar seguia o princípio da legalidade; f) } \\
\text { ocupava o preso com trabalho por ser melhor instrumento para se } \\
\text { conseguir o propósito reabilitador da pena; g) o trabalho era remunerado; } \\
\text { h) criou no condenado a ideia de que ele deveria ser corresponsável pela } \\
\text { segurança do estabelecimento, em respeito aos seus hábitos de } \\
\text { subordinação e moralidade; i) concedia liberdade condicional, reduzindo } \\
\text { um terço da condenação como recompensa à boa conduta do preso; j) } \\
\text { concessão de licenças e saídas temporária dos presos; e l) considerar } \\
\text { benéfica a integração de grupos de presos mais ou menos homogêneos. }\end{array}$ \\
\hline Borstal & $\begin{array}{l}\text { Implantado para jovens delinquentes entre } 16 \text { e } 21 \text { anos, na Inglaterra, em } \\
\text { 1902. O grande avanço desse sistema foi o incentivo ao modelo de regime } \\
\text { penitenciário aberto. Fomentou o surgimento das casas penais abertas. }\end{array}$ \\
\hline
\end{tabular}

Fonte: OLIVEIRA, Edmundo. Origem e Evolução Histórica da Prisão. Pratica jurídica, ano I, n. 2, p. 58 a 61, 31 de maio 2002. p. 58 a 61.

Os modelos de sistema penitenciário acima ditaram o papel do Estado para com o condenado, com o criminoso. Tais modelos eram severos ou brandos, tiveram sucessos ou fracassos. Não obstante, todos focalizaram o processo punitivo de converter o criminoso em não-criminoso, como exclusividade do Estado. Portanto, foram salutares para o desenvolvimento do direito de punir do Estado, ou seja, para formação de um sistema penitenciário imbuído de caráter humanitário e sedimentado em leis.

O Estado de direito contemporâneo tem institucionalizado formas de punição menos severas. Há, portanto, legislações e códigos penitenciários pautados na legalidade e no respeito aos direitos humanos. Contudo, essa não é uma realidade plena em muitos Estados, pois o sistema penitenciário comumente é marcado por estabelecimentos prisionais 
Artigo original

Hegemonia - Revista Eletrônica do Programa de Mestrado em Direitos Humanos, Cidadania e Violência/Ciência Política do Centro Universitário Unieuro

ISSN: 1809-1261

UNIEURO, Brasília, número 26, Janeiro a Junho de 2019, pp. 40-65.

precários, superlotados, maus-tratos, violências, rebeliões, fugas, corrupção ${ }^{4}$. Esse é o caso do Brasil, por exemplo.

É no descompasso entre a legislação e a realidade que se formam grande parte dos problemas dos sistemas penitenciários, e também do direito de punir do Estado. Dessa forma, o Estado, ao invés de fomentar instrumentos de ressocialização pautados no processo de humanização da pena, estimula práticas anacrônicas, pois apenas pune, principalmente com privação da liberdade, sendo que o ideal é punir e ressocializar, fato amplamente previsto na literatura penitenciária.

O sistema penitenciário, portanto, está adstrito ao direito de punir. Sendo assim, falha no sistema penitenciário significa que o Estado está sendo insuficiente em seu direito de punir. Por conta disso, outros problemas podem intensificar-se, como exemplo a criminalidade. Destarte, as mazelas do sistema penitenciário vão muito além dos muros e grades das prisões.

Afinal, o direito de punir do Estado outrora enfrentou dificuldades de legitimidade por impor punições cruéis, que além de mostrarem toda a dinâmica do poder de punição, causavam horrores, passando a perder o respaldo da sociedade. Por sua vez, o Estado hoje encontra dificuldades em estabelecer mecanismos de punição que conduzam à ressocialização, sobretudo diante do excessivo crescimento da população prisional.

O processo de punição acompanhou a evolução do Estado, deixando a escuridão das sentenças escusas, por sentenças que refletem a legalidade e transparência. A humanização da pena, a partir do século XVIII, decorre de modificações das razões do Estado, visto que no Estado de direito as punições corpóreas, torturas e suplícios, passaram para o plano da ilegalidade.

Tem-se, portanto, um deslocamento de seu ponto de aplicação, e por meio desse deslocamento, todo um campo de objetivos recentes, todo um novo regime da verdade e uma quantidade de papéis até então inéditos no exercício da justiça criminal. Aliás, tem-se um saber, com técnicas, discursos “científicos”, que se forma e se entrelaça com a prática do

\footnotetext{
${ }^{4} \mathrm{O}$ profissional-fim do sistema prisional é tipicamente denominado de agente penitenciário. Contudo, existem outras nomenclaturas, tais como: agente prisional, guarda prisional, agente de segurança prisional, agente carcerário etc. Adota-se, a nomenclatura mais conhecida - agente penitenciário.
} 
Artigo original

Hegemonia - Revista Eletrônica do Programa de Mestrado em Direitos Humanos, Cidadania e Violência/Ciência Política do Centro Universitário Unieuro

ISSN: 1809-1261

UNIEURO, Brasília, número 26, Janeiro a Junho de 2019, pp. 40-65.

poder de punir (FOUCAULT, 1987, p. 23). Com efeito, esse processo de "afrouxamento da severidade penal" não representa perda do direito de punir, mas corresponde à uma mudança de foco, cujo intuito é mais subjetivo e menos cruel.

O direito de punir é uma função árdua para qualquer Estado, pois não existe punição perfeita. Como já foi observado, o que a história demonstra é que geralmente se cometem excessos ou faltas. Além disso, aos olhos da vítima, por mais severa e completa que seja a pena, nunca restituirá a situação anterior ao crime. Outrossim, aos olhos do criminoso, por mais cruel que tenha sido, dificilmente considerará justa sua punição. Nesse conflito, cabe ao Estado exercer um direito de punir que não busque a vingança, porém que cumpra sua função social contemporânea, a qual se constitui num elemento de repressão à criminalidade, buscando mecanismos de ressocialização do criminoso.

Enfim, como o sistema penitenciário, ou seja, as prisões, é materialização do direito de punir, logo é preciso vislumbrá-lo como uma instituição cumpridora do papel ressocializador e de inibidor da criminalidade, respeitando os direitos humanos e as legislações penitenciárias. Não obstante, sem comprometer a segurança e os interesses da sociedade. Esse é o atual desafio da punição estatal.

\section{Considerações finais}

O Estado, como responsável pelo direito de punir, transitou da vingança contra o criminoso ao estabelecimento da pena humanizada e reparadora ao ordenamento social. Das trevas e torturas às punições de cerceamento da liberdade, mas garantindo direitos de integridade física ao criminoso. Esse processo, de alguma forma, representa as transformações do próprio Estado. Desse modo, a punição é um recurso político.

A punição ou pena é parte intrínseca do poder político, logo as prisões também. Assim, os dilemas do mundo das prisões não ficam confinados aos muros e grades dessas instituições. Ao contrário eles transbordam e se espalham pela tessitura social. Por isso, destaca-se que, as prisões têm um papel político na contemporaneidade, visto que elas, 
Artigo original

Hegemonia - Revista Eletrônica do Programa de Mestrado em Direitos Humanos, Cidadania e Violência/Ciência Política do Centro Universitário Unieuro

ISSN: $1809-1261$

UNIEURO, Brasília, número 26, Janeiro a Junho de 2019, pp. 40-65.

contraditoriamente representam anomalias nos sistemas de controle social e corporificam a face punitiva do Estado.

Nesse sentido, Foucault sentencia que, a prisão é uma detestável solução, mas não há nada para colocar em seu lugar. Não obstante esse dilema das prisões clama por equacionamento nos dias de hoje, pois, mesmo sendo uma estrutura com eficiência imprecisa, cada vez mais indivíduos são encarcerados. Ora, pesquisa do Centro Internacional de Estudos Penitenciários (ICPS), de 2013, já estimava a população carcerária mundial em 10,2 milhões de indivíduos 5 .

Governar esse contingente de indivíduos encarcerados espalhados por inúmeras prisões mundo afora é uma responsabilidade política, afinal, punir é um direito do Estado. Diante disso, como no passado as punições cruéis e de suplício se voltaram contra o poder político, visto que o povo deixou de acreditar naquelas sentenças de terror; as prisões de hoje têm perdido legitimidade, seja por que são incapazes de transmudar os criminosos, seja por que são estruturas de violência. A situação das prisões no mundo de hoje, portanto, é a face mais evidente das vicissitudes do direito de punir do Estado, que resinifica o papel dessas instituições ou está sentenciado à perda de sua legitimidade como estrutura punitiva. Eis a questão política das prisões.

8. Referências bibliográficas

BARROS, Ângelo Roncalli de Ramos. Técnicas de Reintegração do Sentenciado. Brasília: Curso de Treinamento de Agente Penitenciário da PCDF, 2002.

BECCARIA, Cesare. Dos Delitos e da Penas. São Paulo: Ed. Martin Claret, 2004.

\footnotetext{
5 População prisional chega a 10,2 milhões no mundo, diz instituto. GI. Disponível em: http://g1.globo.com/mundo/noticia/2013/12/populacao-prisional-chega-102-milhoes-no-mundo-dizinstituto.html. Particularmente, no caso brasileiro, registra-se a maior população prisional da América Latina e a terceira maior do mundo, ${ }^{5}$ com 726.712 mil presos, conforme dados do Departamento Penitenciário (DEPEN), de junho de 2016. Levantamento Nacional DE INFORMAÇÕES PENITENCIÁRIAS. Ministério da Justiça, 2017. Disponível em: https://www.conjur.com.br/dl/infopen-levantamento.pdf
} 
Artigo original

Hegemonia - Revista Eletrônica do Programa de Mestrado em Direitos Humanos, Cidadania e Violência/Ciência Política do Centro Universitário Unieuro

ISSN: $1809-1261$

UNIEURO, Brasília, número 26, Janeiro a Junho de 2019, pp. 40-65.

BOBBIO, Noberto. Liberalismo e Democracia. São Paulo: Ed. Brasiliense, 1997.

CURSO DE FORMAÇÃO de Agente Penitenciário da Policia Civil do DF. Noções de Direito Penitenciário, 2001.

FANDINO MARINO, Juan Mario. Comparative analysis of the effects of socioeconomic status, crime type and prison conditions on criminal recidivism. Sociologias. [online]. July/Dec. 2002, no.8 [cited 21 December 2005], p.220-244. Available from World Wide Web. Disponível em: http://www.scielo.br/scielo. ISSN 1517-4522.

FOUCAULT, Michel. Vigiar e Punir. Petrópolis: Ed. Vozes, 1987.

A verdade e as formas jurídicas. Rio de Janeiro: Ed. Nau, 2003.

GONÇALVES, Pedro Correia. A era do humanitarismo penitenciário: as obras de John Howard, Cesare Beccaria e jeremy Bentham. Revista da Faculdade de Direito da UFG, v. 33, n. 1, p. 917, 2009.

HOBBES, Thomas. Leviatã. São Paulo: Ed. Martin Claret, 2003.

LOCKE, Jonh. Segundo Tratado Sobre o Governo. São Paulo, Ed. Martin Claret, 2004.

MARCHETTI, 2002:416-434, in WACQUANT, Loïc. A aberração carcerária à moda francesa. Dados, v. 47, n.2, Rio de Janeiro, 2004.

MINHOTO, Laurindo Dias. As Prisões de Mercado. Lua Nova, n.55-56, São Paulo, 2002.

NETO, Theodomiro Dias. Confins da Pena. Disponível em: http://www.ilanud.org.br/index.php?cat_id=92\&pag_id=553.

OLIVEIRA, Edmundo. Educação e formação profissional do preso na América Latina. Pratica Jurídica, ano I, n. 8, p. 53, 30 de nov. 2002a.

. Origem e Evolução Histórica da Prisão. Pratica Jurídica, ano I, n. 1, p. 58, 30 abr. 2002b. 
Artigo original

Hegemonia - Revista Eletrônica do Programa de Mestrado em Direitos Humanos, Cidadania e Violência/Ciência Política do Centro Universitário Unieuro

ISSN: $1809-1261$

UNIEURO, Brasília, número 26, Janeiro a Junho de 2019, pp. 40-65.

ROLIM, Marcos. Prisão e Ideologia: limites e possibilidades para a reforma prisional no Brasil. Centre for Brazilian Studies, University of Oxford, Working Paper, march, 2004.

SALLA, Fernando. As prisões em São Paulo: 1822-1940. São Paulo: Annablume/Fapesp, 1999.

THOMPSON. A. A questão Penitenciária. Rio de Janeiro: Ed. Forense, 1980.

VEIGA, Marcio Gai. Lei de Crimes Hediondos: uma abordagem crítica. Jus Navigandi,

WACQUANT, Loïc. A aberração carcerária à moda francesa. Dados, 2004, vol.47, no.2, p.215-232. ISSN 0011-5258

- As Prisões da Miséria. Rio de Janeiro: Ed. Jorge Zahar, 2001.

WEBER, Max. "A Política como vocação". In: Ciência e política. Duas vocações. $16^{\mathrm{a}} \mathrm{ed}$. tradução de Leônidas Hegenberg e Octany Silveira da Mota. - São Paulo: Editora Cultrix, 2000.

ZAFFARONI, E. Raul; BATISTA, Nilo; ALAGIA, Alejandro; SLOKAR, Alejandro. Direito Penal Brasileiro - Primeiro Volume. Rio de Janeiro: Revan, 2003.

.; REP, Miguel. La cuestión criminal. Planeta, 2013. 